\title{
Pengaruh pemberian ekstrak daun pepaya (Carica papaya Linn) dan kunyit (Curcuma domestica) terhadap fermentabilitas rumen Sapi Perah in vitro
}

\section{The Effects of Papaya Leaves and Turmeric Extracts supplementation on in vitro ruminal fermentability of Dairy Cow}

\author{
Annisa Ramandhani, Dian Wahyu Harjanti*, Anis Muktiani \\ Fakultas Peternakan dan Pertanian Universitas Diponegoro Semarang \\ Submitted : 02 October 2017, Accepted : 06 January 2018
}

\begin{abstract}
ABSTRAK : Penelitian bertujuan untuk mengetahui pengaruh pemberian ekstrak daun pepaya, ekstrak kunyit dan kombinasi dari keduanya terhadap $\mathrm{pH}$ rumen, konsentrasi amonia $\left(\mathrm{NH}_{3}\right)$, Volatile Fatty Acids (VFA), Asetat, Propionat, Butirat, Metan $\left(\mathrm{CH}_{4}\right)$ dan $\mathrm{CO}_{2}$ serta Protein Total. Materi yang digunakan adalah cairan rumen sapi perah, ekstrak daun pepaya dan esktrak kunyit. Rancangan percobaan yang digunakan adalah Rancangan Acak Lengkap (RAL) dengan 4 perlakuan dan 4 ulangan. Perlakuan yang digunakan adalah ransum kontrol (T1); ransum kontrol dengan penambahan $0.005 \mathrm{ml}$ ekstrak daun pepaya (T2); ransum kontrol dengan penambahan ekstrak kunyit (T3); ransum kontrol dengan penambahan $0.0025 \mathrm{ml}$ ekstrak daun pepaya dan $0.0025 \mathrm{ml}$ ekstrak kunyit (T4). Analisis sample dilakukan setelah 3 jam fermentasi. Data dianalisis menggunakan analisis varian dan dilanjutkan dengan uji jarak berganda Duncan. Hasil menunjukkan bahwa pemberian ekstrak daun pepaya, ekstrak kunyit dan kombinasi dari kedua herbal tidak memberikan pengaruh nyata terhadap $\mathrm{pH}$ rumen, $\mathrm{NH}_{3}, \mathrm{CO}_{2}$ dan nilai protein total. Akan tetapi, dapat meningkatkan kosentrasi VFA total, asetat, propionat, butirat dan metan. Kombinasi dari ekstrak daun pepaya dan ekstrak kunyit memberikan hasil yang tinggi terhadap konsentrasi VFA (445 mMol/l), asetat $(13.4 \mathrm{mMol} / \mathrm{l})$, propionat $(4.24 \mathrm{mMol} / \mathrm{l})$, butirat $(1.87 \mathrm{mMol} / \mathrm{l})$ dan $\mathrm{CH}_{4}(17.17 \%)$ dalam rumen. Simpulan dari penelitian ini adalah pemberian ekstrak daun pepaya, ekstrak kunyit dan kombinasi dari kedua herbal dapat meningkatkan fermentabilitas rumen sapi perah.
\end{abstract}

Kata kunci: daun pepaya, kunyit, fermentasi rumen, sapi perah, in vitro

\begin{abstract}
This research was conducted to determine the effect of using papaya leaves extract, turmeric extract and the combination on ruminal $\mathrm{pH}$, the concentrations of amonia $\left(\mathrm{NH}_{3}\right)$, Volatile Fatty Acids (VFA), Acetate, Propionate, Butyrate, Methane $\left(\mathrm{CH}_{4}\right), \mathrm{CO}_{2}$ and Total Protein. The material was used rumen fluid of dairy cows, papaya leaves extract and turmeric extract. The study was arranged in a completely randomized design with 4 treatments and 4 replications. The treatment was control diet (T1); control diet supplemented with $0.005 \mathrm{ml}$ papaya leaves extract (T2); control diet supplemented with $0.005 \mathrm{ml}$ turmeric extract (T3) and control diet supplemented with $0.0025 \mathrm{ml}$ papaya leaves extract and $0.0025 \mathrm{ml}$ turmeric extract (T4). The rumen fluid was analyzed after 3 hours fermentation. Data were analyzed using ANOVA and continued by Duncan test. The result showed that single supplementation of either papaya leaves or turmeric extract alone and supplementation of both herbal did not affect ruminal $\mathrm{pH}, \mathrm{NH}_{3}, \mathrm{CO}_{2}$ and total protein production. Moreover, there were an increase in concentrations of total VFA, acetate, propionate, butyrate and methane. The combination of papaya leaves and turmeric extract supplementation resulting in the highest concentrations of VFA (445 mMol/l), acetate (13.5 $\mathrm{mMol} / \mathrm{l})$, propionate $(4.24 \mathrm{mMol} / \mathrm{l})$, butyrate $(1.87 \mathrm{mMol} / \mathrm{l})$ and $\mathrm{CH}_{4}(17.17 \%)$ in the rumen. In conclusion, supplementation of papaya leaves and turmeric alone, and the combination of both herbal could enhance rumen fermentability of dairy cow.
\end{abstract}

Keyword: Papaya leaves, turmeric, rumen fermentation, dairycow

*Corresponden author : dianharjanti@undip.ac.id

DOI: 10.21776/ub.jiip.2018.028.01.08 


\section{PENDAHULUAN}

Produktivitas sapi perah di Indonesia saat ini masih rendah. Rendahnya produktivitas tersebut karena jenis dan kandungan nutrisi pakan yang diberikan belum bisa memenuhi kebutuhan ternak. Kualitas pakan mempengaruhi proses dan produk fermentasi yang dihasilkan dalam rumen. Rumen merupakan bagian terbesar dari lambung ternak ruminansia. Beberapa jenis mikroorganisme seperti bakteri, protozoa dan fungi yang berperan dalam proses pencernaan, hidup dan berkembangbiak dalam rumen. Populasi protozoa yang meningkat kurang menguntungkan, karena sifatnya sebagai predator bakteri untuk memenuhi kebutuhan asam amino dalam sintesis protein sehingga laju degrdasi protein berkurang dan fermentasi dalam rumen terganggu. Bakteri penghasil metan (metanogenik) sekitar 30\% bersimbiosis dengan protozoa.

Sektor peternakan, khususnya ternak ruminansia menyumbang sebesar 37\% produksi metan (Martin dkk., 2008). Penurunanan produksi metan dapat dicapai, jika protozoa dalam rumen dapat dikurangi jumlahnya (defaunasi). Saponin berfungsi sebagai agen defaunasi sehingga mampu menurunkan produksi metan dan menekan populasi protozoa (Suparjo, 2008). Saponin mampu membentuk ikatan kompleks dengan sterol yang terdapat pada permukaan membran protozoa. Tanin merupakan senyawa antinutrisi yang memiliki gugus fenol, selain sebagai agen defaunasi juga berfungsi untuk memproteksi protein (Wahyuni dkk., 2014).

Daun pepaya dan kunyit merupakan salah satu tanaman yang dapat dimanfaatkan sebagai agen defaunasi. Kandungan senyawa aktif berupa saponin dan tanin yang terdapat pada daun pepaya dan kunyit dapat dimanfaatkan sebagai agen defaunasi yaitu mengurangi jumlah protozoa sehingga bakteri aman dari gangguan protozoa dan meningkatkan proses fermentasi dalam rumen. Saponin dan tanin mampu membentuk ikatan sterol dalam dinding sel protozoa dan menyebabkan tegangan pada permukaan membran sel protozoa serta menyebabakan lisis pada sel, sedangkan membran sel bakteri lebih tahan terhadap saponin dan tanin karena dinding selnya berupa peptidoglikan. Penambahan agen defaunasi dalam pakan dapat meningkatkan fermentabilitas pakan, karena jumlah protozoa berkurang dan bakteri dalam rumen dapat mendegradasi pakan dengan baik sehingga fermentabilitas pakan meningkat.

Beberapa penelitian telah dilakukan dengan pemberian tepung daun pepaya dan ekstrak daun pepaya dapat meningkatkan produksi $\mathrm{NH}_{3}$, VFA dan sintesis protein mikrobia secara in vitro (Sairullah dkk., 2016). Penelitian lain menggunakan tepung kunyit untuk meningkatkan fermentabilitas pakan secara in vitro (Wahyuni, 2008). Penelitian tentang pemanfaatan ekstrak daun pepaya dan kunyit sebagai agen defaunasi masih perlu dikaji lebih dalam untuk mengetahui seberapa besar pengaruhnya terhadap fermebtabilitas pakan sapi perah seara in vitro.

Tujuan dari penelitian ini yaitu untuk mengetahui pengaruh pemberian ekstrak daun pepaya dan ekstrak kunyit serta kombinasi dari kedua herbal terhadap fermentabilitas pakan sapi perah secara in vitro. Manfaat dari penelitian ini memperoleh informasi mengenai pengujian herbal yang ditambahkan dalam pakan sebagai agen defaunasi secara in vitro dan sebagai dasar informasi pada 
penelitian selanjutnya secara in vivo. Hipotesis penelitian ini adalah pemberian ekstrak daun pepaya, kunyit serta kombinasi dari kedua herbal menyebabkan nilai $\mathrm{pH}$ tetap, produksi $\mathrm{NH}_{3}$, VFA total dan parsial serta nilai protein total meningkat dan produksi $\mathrm{CH}_{4}$ dan $\mathrm{CO}_{2}$ menurun.

\section{MATERI DAN METODE}

Materi yang digunakan dalam penelitian adalah cairan rumen sapi perah, ekstrak daun pepaya, ekstrak kunyit, konsentrat komersial dan hijauan dengan perbandingan 50\%: 50\%. Data kandungan nutrient bahan pakan dapat dilihat pada Tabel 1. Kandungan fitokimia pada masing-masing perlakuan dapat dilihat pada Tabel 2. Alat yang digunakan pada tahap pembuatan ekstrak daun pepaya dan ekstrak kunyit adalah oven, blender, rotary evaporator. Alat yang digunakan untuk analisis adalah tabung dan tutup tabung fermentor, penangas air (waterbath), tabung gas $\mathrm{CO}_{2}$, sentrifuge dengan kecepatan 300 rpm, pH elektronik, cawan conway, alat titrasi, alat destilasi, erlenmayer, tabung reaksi, pipet ukur, pipet tetes, gelas beker, kertas saring, labu destruksi. Bahan yang digunakan adalah larutan McDougall, $\mathrm{H}_{2} \mathrm{SO}_{4}$, aquades, $\mathrm{NaOH} 0,5 \mathrm{~N}, \mathrm{HCl} 0,5 \mathrm{~N}, \mathrm{NaOH} 45 \%$, TCA (Trichlor Acetic Acid), SSA (Sulfosalicilic Acid), $\mathrm{H}_{3} \mathrm{BO}_{3}$, indikator phenolptalein $1 \%$, indikator methyl red dan brom cresol green, $\mathrm{H}_{2} \mathrm{SO}_{4} 0,0055 \mathrm{~N}$, HCL $0,1 \mathrm{~N}$.

Tabel 1. Kandungan nutrien bahan pakan

\begin{tabular}{lccccccc}
\hline \multicolumn{1}{c}{ Bahan pakan } & BK & Abu & PK & LK & SK & BETN & TDN \\
\hline & ------------ & \\
Rumput Gajah & 82,70 & 18,05 & 12,23 & 4,46 & 38,67 & 26,59 & 51,51 \\
Konsentrat & 84,33 & 15,70 & 11,80 & 4,91 & 6,72 & 60,87 & 79,54 \\
Tepung Daun & 84,08 & 16,45 & 13,58 & 2,89 & 19,10 & 47,98 & 67,27 \\
Pepaya & 87,30 & 14,39 & 11,95 & 4,56 & 15,47 & 53,63 & 71,86 \\
Tepung Kunyit & & & & & & & \\
\hline
\end{tabular}

Tabel 2. Bahan aktif dari esktrak yang ditambahkan pada masing-masing perlakuan

\begin{tabular}{ccccc}
\hline \multirow{2}{*}{ Zat aktif } & \multicolumn{4}{c}{ Perlakuan } \\
\cline { 2 - 5 } & T1 & T2 & T3 & T4 \\
\hline Saponin & ----------- & 0,178 \\
Alkaloid & 0 & 0,171 & 0,186 & 0,020 \\
Steroid & 0 & 0,028 & 0,012 & 0,100 \\
Flavonoid & 0 & 0,124 & 0,077 & 0,165 \\
Tanin & 0 & 0,234 & 0,096 & 2,382 \\
Fenol & 0 & 2,699 & 2,066 & 1,133 \\
\hline
\end{tabular}

\section{Metode penelitian}

Metode penelitian terdiri dari 3

tahap yaitu pembuatan ekstrak, pengambilan cairan rumen dan analisis sesuai dengan parameter. Penelitian dilakukan secara in vitro. Rancangan percobaan yang digunakan adalah 
Rancangan Acak Lengkap (RAL) dengan 4 perlakuan dan masing-masing 4 ulangan. Dosis perlakuan adalah $0,03 \%$ bobot badan ternak, dengan kebutuhan BK 3\% dan estimasi bobot badan sapi perah 400 $\mathrm{kg}$. kombinasi perlakuan yang digunakan sebagai berikut.

$\mathrm{T} 1=$ ransum kontrol $0,5 \mathrm{~g}$

$\mathrm{T} 2=$ ransum kontrol $0,5 \mathrm{~g}+$ ekstrak daun pepaya $0,005 \mathrm{ml}$

$\mathrm{T} 3=$ ransum kontrol 0,5 g + ekstrak kunyit $0,005 \mathrm{ml}$

$\mathrm{T} 4$ = ransum kontrol $0,5 \mathrm{~g}+$ ekstrak daun pepaya $0,0025 \mathrm{ml}+$ ekstrak kunyit $0,0025 \mathrm{ml}$

\section{Pembuatan ekstrak}

Pembuatan ekstrak dilakukan dengan cara daun pepaya dan kunyit dicuci bersih, kemudian dipotong kecil-kecil, dikeringkan dalam oven dengan suhu $50^{\circ} \mathrm{C}$ selama 24 jam. Daun pepaya dan kunyit yang telah kering kemudian dihaluskan menggunakan blender. Bahan yang telah halus kemudian direndam atau dilakukan perendaman (maserasi) menggunakan pelarut ethanol $96 \%$ selama 8 -12 jam pada suhu ruang atau suhu kamar. Larutan yang telah direndam, kemudian disaring menggunakan kain kasa. Prosedur penyaringan tersebut diulang sampai hasil filtrat mendekati warna pelarut (tersaring sempurna) dan dimasukkan dalam labu pemisah. Filtrat yang telah siap kemudian diekstraksi menggunakan alat rotary evaporator dengan suhu $40-60^{\circ} \mathrm{C}$ selama 60 menit hingga pelarut tidak tertinggal dalam sampel, jika masih tercium bau pelarut maka proses rotary evaporator dilakukan kembali. Ekstrak yang sudah jadi kemudian dimasukkan dalam wadah kaca.

\section{Pengambilan cairan rumen}

Pengambilan cairan rumen dilakukan dengan cara pemerasan isi rumen menggunakan kain sebanyak 4 rangkap. Setelah cairan rumen didapat kemudian dimasukkan dalam termos, yang sebelumnya telah diisi air panas sampai suhu dalam termos mencapai $39^{\circ} \mathrm{C}$ atau sesuai dengan keadaan suhu dalam rumen. Selanjutnya termos ditutup rapat dan dibawa ke laboratorium untuk dianalisis.

\section{Pengukuran pH, analisis produksi $\mathrm{NH}_{3}$ dan VFA total}

Pengukuran $\mathrm{pH}$ dilakukan dengan menggunakan $\mathrm{pH}$ meter. Produksi $\mathrm{NH}_{3}$ dianalisis menggunakan metode Conway (Conway, 1957). Sedangkan produksi VFA total dianalisis menggunakan metode destilasi uap (Krooman et al., 1967).

\section{Analisis produksi asetat, butirat propionat, $\mathrm{CH}_{4}$ dan $\mathrm{CO}_{2}$}

Analisis dilakukan dengan menggunakan Gas Chromatografi (GC) Chrompack.

\section{Analisis nilai protein total}

Nilai protein total dianalisis menggunakan metode kjdahl (Kjdahl, 1883).

\section{Analisis data}

Data yang diperoleh kemudian diuji menggunakan analisis varian, apabila hasil menunjukkan signifikasi atau berbeda nyata maka dilanjutkan dengan uji jarak berganda Duncan untuk mengetahui perbedaan antar perlakuan (Steel dan Torrie, 1989). 


\section{HASIL DAN PEMBAHASAN}

Berdasarkan penelitian yang telah

dilakukan diperoleh hasil yang dapat

dilihat pada Tabel 3 .

Tabel 3. Fermentabilitas rumen sapi perah akibat suplementasi ekstrak herbal

\begin{tabular}{lcccc}
\hline \multirow{2}{*}{\multicolumn{1}{c}{ Parameter }} & \multicolumn{4}{c}{ Perlakuan } \\
\cline { 2 - 5 } & $\mathrm{T} 1$ & $\mathrm{~T} 2$ & $\mathrm{~T} 3$ & $\mathrm{~T} 4$ \\
\hline Nilai $\mathrm{pH}$ & 7,20 & 7,03 & 7,08 & 7,03 \\
$\mathrm{NH}_{3}(\mathrm{mMol} / \mathrm{l})$ & 4,13 & 5,57 & 4,87 & 5,01 \\
VFA Total $(\mathrm{mMol} / \mathrm{l})$ & $162,5^{\mathrm{C}}$ & $275^{\mathrm{B}}$ & $407,5^{\mathrm{A}}$ & $445^{\mathrm{A}}$ \\
Asetat $(\mathrm{mMol} / \mathrm{l})$ & $8,07^{\mathrm{b}}$ & $12,99^{\mathrm{a}}$ & $12,29^{\mathrm{a}}$ & $13,60^{\mathrm{a}}$ \\
Propionat $(\mathrm{mMol} / \mathrm{l})$ & $2,54^{\mathrm{b}}$ & $4,03^{\mathrm{a}}$ & $3,79^{\mathrm{a}}$ & $4,24^{\mathrm{a}}$ \\
Butirat $(\mathrm{mMol} / \mathrm{l})$ & $1,10^{\mathrm{b}}$ & $1,81^{\mathrm{a}}$ & $1,62^{\mathrm{a}}$ & $1,84^{\mathrm{a}}$ \\
$\mathrm{CH}_{4}(\%)$ & $13,97^{\mathrm{b}}$ & $16,87^{\mathrm{a}}$ & $16,29^{\mathrm{a}}$ & $17,17^{\mathrm{a}}$ \\
$\mathrm{CO}_{2}(\%)$ & 84,36 & 79,63 & 78,51 & 80,99 \\
$\mathrm{Nilai}_{\text {Nilotein total }(\mathrm{mg} / \mathrm{g})}$ & 190,60 & 121,33 & 145,56 & 123,28 \\
\hline
\end{tabular}

Keterangan: ab Superskrip yang berbeda pada baris yang sama menunjukkan perbedaan nyata $(\mathrm{P}<0,05)$

${ }^{\mathrm{ABC}}$ Superskrip kapital yang berbeda pada baris yang sama menunjukkan perbedaan sangat nyata $(\mathrm{P}<0,01)$

$\mathrm{T} 1=$ ransum kontrol, $\mathrm{T} 2=$ ransum kontrol + ekstrak daun pepaya $0,005 \mathrm{ml}, \mathrm{T} 3$ $=$ ransum kontrol + ekstrak kunyit $0,005 \mathrm{ml}, \mathrm{T} 4=$ ransum kontrol + ekstrak daun pepaya $0,0025 \mathrm{ml}+$ ekstrak kunyit

\section{Nilai pH rumen}

Pemberian ekstrak daun pepaya, ekstrak kunyit serta kombinasi dari kedua ekstrak tersebut tidak memberikan pengaruh nyata $(\mathrm{P}>0,05)$ terhadap nilai $\mathrm{pH}$. Nilai $\mathrm{pH}$ yang dihasilkan termasuk dalam kategori optimum. Jean (1991) menyatakan bahwa nilai optimum $\mathrm{pH}$ yang diukur setelah dilakukan fermentasi berkisar antara 6,9-7,0. Nilai $\mathrm{pH}$ dalam penelitian mengalami penurunan meskipun secara statistik tidak berbeda nyata. Hal tersebut sejalan dengan produksi VFA yang meningkat dalam penelitian ini. Perbedaan pemberian ekstrak herbal antara ketiga perlakuan tidak memberikan pengaruh nyata terhadap nilai $\mathrm{pH}$. Artinya pemberian ekstrak daun pepaya dan kunyit sebagai pengganti antibiotik tidak memberikan efek negatif terhadap nilai $\mathrm{pH}$ rumen serta dengan penambahan herbal tersebut mampu memperbaiki nilai $\mathrm{pH}$ sehingga aktivitas fermentasi rumen tidak terganggu. Nilai $\mathrm{pH}$ yang optimum menandakan bahwa terjadi degradasi pakan dengan baik sehingga mikroba dalam rumen dapat hidup secara optimum. Cathurvedi et al. (2015) menyatakan bahwa nilai $\mathrm{pH}$ yang optimum menjadi salah satu indikator bahwa pakan tersebut terdegradasi dengan baik, karena pada $\mathrm{pH}$ tersebut mikroba penghasil enzim pencerna serat kasar dapat hidup secara baik dalam rumen. 
Beberapa faktor yang mempengaruhi $\mathrm{pH}$ rumen yaitu proses fermentasi dalam rumen serta produk yang dihasilkan selama proses fermentasi. Orskov (1998) bahwa faktor yang mempengaruhi nilai $\mathrm{pH}$ rumen adalah proses fermentasi dan produk yang dihasilkan dari proses fermentasi. Penggunaan saliva buatan sebagai buffer berpengaruh terhadap nilai $\mathrm{pH}$ rumen. Wanapat et al. (2014) menyatakan bahwa kisaran nilai $\mathrm{pH}$ yang normal karena penggunaan saliva buatan sebagai buffer mampu menjaga kestabilan kondisi rumen selama proses fermentasi. Nilai $\mathrm{pH}$ rumen berperan penting dalam proses fermentasi, karena $\mathrm{pH}$ mendukung pertumbuhan mikroba dan menghasilkan produk fermentasi.

\section{Produksi $\mathrm{NH}_{3}$}

Berdasarkan data yang diperoleh perlakuan pemberian ekstrak daun pepaya, ekstrak kunyit dan kombinasi antara kedua herbal tersebut tidak memberikan pengaruh nyata $(\mathrm{P}>0,05)$ terhadap produksi $\mathrm{NH}_{3}$. Produksi $\mathrm{NH}_{3}$ dalam penelitian ini termasuk dalam kategori normal atau sesuai dengan nilai standar $\mathrm{NH}_{3}$, sehingga dapat menunjang pertumbuhan mikrobia. Menurut Sutardi et al. (1993) menyatakan bahwa konsentrasi $\mathrm{NH}_{3}$ optimum yaitu berkisar antara $4-12 \mathrm{mMol} / \mathrm{l}$ dan rata-rata adalah 8 mMol/l. Paengkoum dkk. (2006) menyatakan bahwa konsentrasi $\mathrm{NH}_{3}$ yang dibutuhkan oleh mikrobia dalam rumen untuk mencerna pakan secara maksimal sebesar 3 - $14 \mathrm{mMol} / \mathrm{l}$.

Produksi $\mathrm{NH}_{3}$ pada penelitian ini meningkat meskipun secara statistik tidak berbeda nyata. Peningkatan produksi $\mathrm{NH}_{3}$ sejalan dengan menurunnya nilai $\mathrm{pH}$ dalam penelitian ini yaitu dari 7,20 menjadi 7,03 meskipun secara statistik Uhi et al. (2006) menyatakan bahwa $\mathrm{pH}$ rumen memiliki peran penting untuk mendukung pertumbuhan mikroba rumen dan menghasilkan produk fermentasi berupa $\mathrm{NH}_{3}$ dan VFA, apabila produksi $\mathrm{NH}_{3}$ dan VFA meningkat maka nilai $\mathrm{pH}$ menurun begitu juga sebaliknya apablia poduksi $\mathrm{NH}_{3}$ dan VFA menurun maka nilai $\mathrm{pH}$ meningkat. Faktor-faktor yang mempengaruhi produksi $\mathrm{NH}_{3}$ adalah jumlah protein dalam pakan, protein yang larut, sumber dan jumlah karbohidrat. Mahesti (2009) menyatakan bahwa produksi $\mathrm{NH}_{3}$ dalam rumen dipengaruhi oleh kandungan protein dalam pakan, $\mathrm{pH}$ rumen, kelarutan protein dalam pakan. Pendapat yang sama dinyatakan oleh Ranjhan (1980) menyatakan bahwa produksi $\mathrm{NH}_{3}$ dipengaruhi oleh beberapa faktor yaitu kadar protein dalam pakan, kelarutan protein, serta sumber dan proporsi karbohidrat yang terlarut.

\section{Produksi VFA total}

Produksi VFA total dari hasil penelitian menunjukkan bahwa perlakuan pemberian ekstrak daun pepaya, ekstrak kunyit serta kombinasi dari keduanya memberikan pengaruh sangat nyata $(\mathrm{P}<0,01)$ terhadap nilai VFA total. Pada perlakuan $\mathrm{T} 4$ atau dengan pemberian kombinasi antara kedua herbal memberikan efek peningkatan produksi VFA total. Hal ini disebabkan karena dalam daun pepaya dan kunyit terdapat senyawa aktif yang berupa saponin. Saponin diduga dapat mengurangi jumlah protozoa sehingga bahan organik dalam pakan mudah terdegradasi karena jumlah bakteri meningkat sehingga fermentasi dalam rumen meningkat.

Hasil uji fitokimia kandungan saponin daun pepaya dan kunyit pada masing-masing kelompok yaitu pada kelompok T2 sebesar $0,171 \mu \mathrm{g}$, pada 
kelompok T3 sebesar 0,186 $\mu \mathrm{g}$ dan pada kelompok T4 sebesar $0,178 \mu \mathrm{g}$, sehingga menyebabkan peningkatan nilai VFA total. Astuti et al. (2008) menyatakan bahwa saponin mampu menurunkan populasi protozoa dalam rumen karena saponin membentuk ikatan kompleks dalam sterol dari membrane sel protozoa dan menyebabkan terjadinya lisis pada sel.

Suharti et al. (2009) menyatakan bahwa saponin mampu membentuk ikatan sterol dalam dinding sel protozoa dan menyebabkan tegangan pada permukaan membran sel protozoa, sedangkan membran sel bakteri lebih tahan terhadap saponin karena dinding selnya berupa peptiglokigan. Produksi VFA yang tinggi menandakan bahwa bahan organik yang terkadung dalam pakan sangat mudah didegradasi oleh bakteri rumen. McDonald et al. (2011) menyatakan bahwa tingkat produksi VFA yang tinggi merupakan sebuah indikator dimana bahan organik yang terkandung dalam pakan atau ransum mudah untuk didegradasi oleh bakteri rumen sehingga menyebabkan $\mathrm{pH}$ rumen menurun.

$$
\text { Beberapa faktor yang }
$$

mempengaruhi produksi VFA adalah $\mathrm{pH}$ rumen, kecernaan bahan pakan dan jenis mikroba dalam rumen. Ensminger et al. (1990) menyatakan bahwa tinggi dan rendahnya konsentrasi VFA dipengaruhi oleh peningkatan mikrobia yang dapat meningkatkan aktivitas fermentasi sehingga mempengaruhi konsentrasi VFA. Tingginya konsentrasi VFA menunjukkan bahwa pakan tersebut mudah difermentasi dalam rumen. Arora (1995) menyatakan bahwa faktor yang mempengaruhi tinggi dan rendahnya produksi VFA adalah fermentabilitas pakan, jumlah karbohidrat yang mudah larut dan $\mathrm{pH}$ rumen.

DOI: 10.21776/ub.jiip.2018.028.01.09

\section{Produksi asetat, propionat dan butirat}

Pemberian ekstrak daun pepaya, ekstrak kunyit serta kombinasi dari keduanya memberikan pengaruh nyata $(\mathrm{P}<0,05)$ terhadap produksi asetat, butirat dan propionat. Pada perlakuan T4 atau dengan perlakuan kombinasi antara ekstrak daun pepaya dan kunyit dapat meningkatkan produksi asetat, propionat dan butirat. Hal ini disebabkan karena adanya aktivitas antioksidan yang berupa saponin yang terkandung dalam daun pepaya dan kunyit. Berdasarkan uji fitokimia daun pepaya dan kunyit pada masing-masing perlakuan memilki kandungan saponin yaitu pada T2 sebesar $0,171 \mu \mathrm{g}$, T3 sebesar $0,186 \mu \mathrm{g}$ dan $\mathrm{T} 4$ sebesar $0,178 \mu \mathrm{g}$.

Menurut Lila et al. (2005) menyatakan bahwa pemberian saponin dapat meningkatkan produksi VFA baik secara in vivo ataupun secara in vitro, dengan cara saponin mengurangi populasi protozoa sehingga mikroba dalam rumen meningkat dan menyebabkan proses fermentasi rumen meningkat serta meningkatkan produksi VFA. Menurut Lourenco et al. (2008) menyatakan bahwa pemberian saponin dapat meningkatkan produksi VFA serta meningkatkan aktivitas mikrobia dalam rumen. Selain dipengaruhi oleh senyawa aktif yang berupa saponin, peningkatan produksi asetat, propionat dan butirat juga diduga dipengaruhi oleh adanya senyawa aktif yang berupa flavonoid yang terkadung dalam daun pepaya dan kunyit. Berdasarkan uji fitokimia kandungan senyawa flavonoid daun pepaya dan kunyit pada masing-masing perlakuan yaitu T2 0,234 $\mu \mathrm{g}$, T3 sebesar 0,096 $\mu \mathrm{g}$ dan T4 sebesar 0,165 $\mu \mathrm{g}$. Menurut Mardalena (2015) menyatakan bahwa flavonoid merupakan komponen bioaktif pada tanaman yang mempunyai pigmen 
yang terdiri dari senyawa polifenol dan memiliki aktivitas sebagai antioksidan, sehingga dapat meningkatkan fermentasi dalam rumen.

\section{Produksi $\mathrm{CH}_{4}$ dan $\mathrm{CO}_{2}$}

Berdasarkan data yang diperoleh pemberian masing-masing ekstrak herbal tersebut dan kombinasi antara kedua ekstrak memberikan pengaruh dalam peningkatan nilai produksi $\mathrm{CH}_{4}$. Pada perlakuan T4 atau dengan perlakuan kombinasi antara ekstrak daun pepaya dan kunyit dapat meningkatkan produksi $\mathrm{CH}_{4}$. Meningkatnya produksi $\mathrm{CH}_{4}$ disebabkan karena produksi asetat dan butirat dalam penelitian meningkat. Proses pembentukan asetat dan butirat menghasilkan $\mathrm{H}_{2}$, dimana $\mathrm{H}_{2}$ digunakan bersama $\mathrm{CO}_{2}$ untuk menghasilkan $\mathrm{CH}_{4}$. Widyawati (2009) menyatakan bahwa $\mathrm{CH}_{4}$ terbentuk dari $\mathrm{CO}_{2}$ dan $\mathrm{H}_{2}$ yang terbentuk selama proses fermentasi. Meningkatnya propionat dapat menurunkan produksi $\mathrm{CH}_{4}$ karena pembentukan propionat lebih banyak menggunakan $\quad \mathrm{H}_{2}, \quad$ sedangkan pembentukan asetat dan butirat menghasilkan $\mathrm{H}_{2}$.

Widiawati et al. (2010) menyatakan bahwa tingginya produksi dan konsentrasi $\mathrm{CH}_{4} \quad$ mengindikasikan besarnya energi pakan yang terbuang sehingga dapat menurunkan efisiensi pakan. Meningkatnya $\mathrm{CH}_{4}$ juga disebabkan karena kandungan serat kasar dalam ransum lebih tinggi dibandingkan dengan kandungan protein. Wahyono et al. (2017) menyatakan bahwa tanaman yang berkualitas baik mempunyai protein yang lebih tinggi dan menghasilkan $\mathrm{CH}_{4}$ yang lebih sedikit dibandingkan dengan pakan yang mengandung banyak serat atau sulit dicerna.
Pemberian ekstrak daun pepaya, ekstrak kunyit serta kombinasi dari keduanya tidak memberikan pengaruh nyata $(\mathrm{P}>0,05)$ terhadap produksi $\mathrm{CO}_{2}$. Gas $\mathrm{CO}_{2}$ merupakan komponen utama yang penting dalam pembentukan gas metan (metanogenesis). Bhatta et al. (2009) menyatakan bahwa hidrogen $\left(\mathrm{H}_{2}\right)$ dan $\mathrm{CO}_{2}$ merupakan komponen utama dalam proses metanogenesis. Widiawati et al. (2010) menyatakan bahwa $\mathrm{CO}_{2}$ berperan dalam pembentukan metan dengan cara asetat melepaskan fraksi hidrogen dan berikatan dengan $\mathrm{CO}_{2}$ kemudian membentuk metan.

\section{Nilai protein total}

Pemberian ekstrak daun pepaya, ekstrak kunyit serta kombinasi dari kedua ekstrak tersebut tidak memberikan pengaruh nyata $(\mathrm{P}>0,05)$ terhadap nilai protein total Protein total merupakan gabungan dari protein by pass dalam pakan yang lolos dari degradasi dan protein mikrobia yang dihasilkan dalam rumen. Jenny et al. (2012) menyatakan bahwa protein total merupakan gabungan antara protein by pass yaitu berupa proten pakan yang lolos dari proses degradasi dalam rumen dan protein mikrobia.

Nilai protein total yang tidak berbeda nyata pada penelitian ini sejalan dengan produksi $\mathrm{NH}_{3}$ yang tidak berbeda nyata. Dijkstra (1994) menyatakan bahwa degradasi protein selain memproduksi $\mathrm{NH}_{3}$ juga berperan dalam produksi VFA, apabila produksi $\mathrm{NH}_{3}$ menurun maka nilai protein total juga menurun dan produksi VFA meningkat begitu juga jika produksi $\mathrm{NH}_{3}$ yang tidak berbeda nyata maka nilai protein total juga tidak berbeda nyata. Selain itu nilai protein total yang tidak berbeda nyata diduga karena ransum yang digunakan pada penelitian sama, kandungan protein dalam ransum sama, 
sehingga nilai protein total yang dihasilkan tidak berbeda nyata. Cahyani et al. (2012) bahwa protein pakan yang berupa protein murni ataupun non-protein nitrogen (NPN) mengalami proses proteolisis oleh mikrobia rumen. Protein dirombak menjadi oligopeptida dan asam amino yang kemudian terdeaminasi oleh asam alfa keto, VFA, $\mathrm{CO}_{2}$, dan $\mathrm{NH}_{3}$. Produksi $\mathrm{NH}_{3}$ dan VFA digunakan untuk proses sintesis protein mikrobia dan mendukung pertumbuhan serta meningkatkan populasi mikroba rumen.

\section{KESIMPULAN}

Kesimpulan dari hasil penelitian ini adalah pemberian ekstrak daun pepaya, ekstrak kunyit serta kombinasi dari kedua herbal memberikan pengaruh nyata terhadap fermentasi rumen ditandai dengan produksi VFA total, produksi asetat, produksi propionat, produksi butirat dam produksi $\mathrm{CH}_{4}$ meningkat serta tidak memberikan efek negatif terhadap fermentasi rumen ditandai dengan nilai $\mathrm{pH}$ dan produksi $\mathrm{NH}_{3}$ dalam kisaran normal.

\section{DAFTAR PUSTAKA}

Arora, S. P. 1995. Pencernaan Mikroba Pada Ruminansia. Diterjemahkan Oleh: Retno Murwani. Gadjah Mada University Press, Yogyakarta

Astuti, D. A., S. Suharti dan E. Wina. 2008. Kecernaan nutrien dan performa produksi sapi potong Pernakan Ongole (PO) yang diberi tepung lerak (Sapindus rarak) dalam ransum. J.Ilmu Ternak dan Veteriner. 14 (3) : $200-207$.

Bhatta, R., Y. Uyeno., K. Tajima., A. Takenaka., Y. Yabutomo., I. Nonaka., O. Enishi dan M. Kurihara.
2009. Difference in the nature of tanins on in vitro ruminal and volatile fatty acid production and methanogenic archaea and protozoal population. J. Dairy. Sci. 92 (10) : $5512-5522$.

Cahyani, R. D., L. K. Nuswantara dan A. Subrata. 2012. Pengaruh proteksi protein tepung kedelai dengan tanin daun bakau terhadap konsentrasi amonia, undegraded protein dan protein total secara in vitro. J. Anim. Agric. 1 (1) : 159 - 166.

Cathurvedi, I., T. K. Duta dan A. Sharma. 2015. Effect Of Combined Herbal Feed Additives On Methane, Total Gas Production And Runen Fermentation. J. Biomed. Infor. 11 (5) : $261-266$.

Dijkstra, j. 1994. Production and absorbsion of volatile fatty acids in the rumen. J. Lives. Prod. Sci. 39 (4) : 61 -69.

Esminger, M. E., J. E. Oldfield dan W. W. Heinemann. 1990. Feed And Nutrition Formelly, Feed And Nutrition Complete. Edisi kedua. The Esminger Pub, California.

Jean, B. C. 1991. Rumen Disfunction. In Jounay, J. P. (Ed), Rumen Microbial Metabolism and Ruminant Digestion. INRA Editions, Paris.

Jenny, I., Surono., M. Christiyanto. 2012. Produksi amonia, undegraded protein dan protein total secara in vitro bungkil biji kapuk yang diproteksi dengan tanin alami. J. Anim. Agric. 1 (1) : 277 -284. 
Lila, Z. A., N. Mohammed., S. Kanda., T. Kamada dan H. Itabhasi. 2005. Effect of saponin on ruminal fermentation with particular reference to methane production in vitro. J. Dairy. Sci. 86 (11) : 3330 3336.

Lourenco, M., P. W. Cardozo., S. Calsamiglia dan V. Fieve. 2008. Effect of saponins, quercetin, eugenol and cinnamaldehyde on fatty acid biohydrogenation of forage polyunsaturated fatty acid in dual flow continous culture fermenter. J. Anim. Sci. 86 (12) : $3045-3053$.

Mahesti, G. 2009. Pemanfaatan Protein Pada Domba Lokal Jantan Dengan Bobot Badan Dan Aras Pemberian Pakan Yang Berbeda.Fakultas Peternakan dan Pertanian, Universitas Diponegoro, Semarang. (Tesis).

Mardalena. 2015. Evaluasi serbuk kulit nanas sebagai sumber antioksidan dalam ransum kambing perah peranakan etawah secara in vitro. J. Ilmu-ilmu Peternakan. 18 (1) : 14 21.

Martin, J., J. Rovel., J.P Jouny., M. Doreau., Y. Chiliard. 2008. Methane output and diet digestibility in respon to feeding diary cows crude linseed, extruded linseed of linseed oil. J. Anim. Sci. 86 (30) : 2642 2650.

Mc.Donald, P., Edwards, R.A., and J.F.D. Greenhalgh. 2011. Animal Nutrition, Fourth Edition, Longman London and New York.
Nurhayati., C. U. Wirawati dan D. D. Putri. 2015. Penggunaan produk fermentasi dan kunyit dalam pakan terhadap performa ayam pedaging dan in come over feed ang chick cost. J. Zootek. 35 (2) : 379 - 389.

Orskov, E. R. 1998. The Feeding Of Ruminant Principle And Practice. Edisi Kedua. Chalcombe Publications, United Kingdom

Ranjhan, S.K. 1980. Animal Nutrition in Tropic. Vikas Publishing House. Pvt. Ltd, New Delhi.

Sairullah, P., S. Chuzaemi dan H. Sudarwati. 2016. Effect of flour and papaya leaf extract (Carica papaya L) in feed to amonia concentration, volatile fatty acids and microbial protein syhnthesis in vitro. J.

Ternak Tropika. 17 (2) : 66 -73.

Suharti, S., A. Kurniawati., D. A. Astuti dan E. Wina. 2009. Kecernaan nutrient dan performa produksi sapi potong peranakan ongole (PO) yang diberi tepung lerak (Sapindus rarak) dalam ransum. J. Ilmu Ternak dan Veteriner. 14 (3) : 200 -207.

Supar. 1997. Mastitis subklinis di Indonesia: masalah dan pendekatannya. J. Wartozoa. 6 (2) : $48-52$.

Sutardi, T., D. Sastradipradja., T. Toharmat., S. Anita., Tjakradidjaja dan I. G. Permana. 1993. Peningkatan produksi ternak ruminansia melalui amoniasi pakan serat bermutu terhadap degradasi dalam rumen. J. Anim. Sci. 28 (6) : $67-74$. 
Sutarpa dan Sutama. 2008. Daun pepaya dalam ransum menurunkan kolesterol pada serum dan telur ayam. J. Veteriner. 9 (3) : 152 -156.

Tasripin, D.S. Pengaruh Pemberian Ransum Berimbuhan Kunyit, Zn Proteinat Dan $\mathrm{Cu}$ Proteinat Terhadap Penurunan Status Mastitis Subklinis Pada Sapi Perah Fries Holland. Prosiding Seminar Nasional Teknologi Peternaka dan Veteriner, Bogor, 10 - 11 November 2009. Puslitbang Peternakan, Bogor. $115-120$.

Uhi, H. T., A. Parakkasi dan B. Haryanto. Pengaruh suplemen katalik terhadap karakteristik dan populasi mikroba rumen pada domba. J. Media Peternakan. 29 (1) : 20 -26.

Wahyono, T., W. T. Sasongko., M. Sholihah dan M. Ratnasari. 2017. Pengaruh penambahan tanin daun nangka (Artocarpus heterophyllus) terhadap nilai biologis daun kelor (Moringa Oleifera) dan jerami kacang hijau (Vigna radiata) secara in vitro. J. Buletin Peternakan. 41 (1) : 15 -25.

Wanapat, M., A. Cherdtong., P. Pakdee and S. Wanapat. 2014. Manipulation of rumen ecology by dietary lemongrass powder supplementation. J. Anim Sci. 86 (3) : 3497 - 3503

Widiawati, Y., M. Winugraha dan P. Mahyuddin. 2010. Estimasi Produksi Gas Metana Dari Rumput Dan Tanaman Leguminosa Yang Diukur Secara In Vitro. Prosiding
Seminar Nasional Teknologi Peternakan dan Veteriner. Bogor, 3 - 4 Agustus 2010. Puslitbang Peternakan, Bogor. 131 - 136.

Widyawati, S.D. 2009. Perbandingan potensi daun ketepeng dan minyak ikan lemuru sebagai agensia reduksi metan dalam memperbaiki kualitas pakan ternak ruminansia. J. Sains Peternakan. 7 (1) : 1 - 7 . 